\title{
The Application of Multiple Intelligence Theory in Spoken English Improvement
}

\author{
Jinxiang Xue \\ School of Foreign Languages \\ Harbin University of Commerce \\ Harbin, China 150028
}

\begin{abstract}
The Multiple Intelligence Theory, as a new relatively theory in education reform, has brought much beneficial enlightenment to university teaching reformers and English learners. This theory focuses on learners' individual differences in intelligence and pays attention to the development of multiple intelligence, with rich connotations in education and studies. This paper analyzes the problems that learners meet in the process of learning spoken English by exploring integrality, otherness, practicalness and expansibility of the multiple intelligence theory, so as to enlighten us that we should fully consider the individual differences in the practice of study and strive to create an autonomous, situational and diversified learning environment.
\end{abstract}

Keywords-Multiple intelligence theory; spoken English; individual differences

\section{INTRODUCTION}

The deepening of globalization and "the Belt and Road" policy urges domestic enterprises recruit those who are not only good at dealing with business, but also have good abilities in spoken English. Researchers are exploring various methods to address this issue in terms of technology and learning and teaching approaches. In recent years, the theory of multiple intelligence is gradually used by researchers and it provides theoretical support for language learners.

This paper analyzes how to develop English speaking abilities from the four aspects-integrality, otherness, practicalness and development. It also analyzes the relevant features and problems and it finally puts forward some suggestions on how to improve business English speaking ability by applying multiple intelligence theory.

\section{MULTIPLE INTELLIGENCE THEORY}

The Theory of Multiple Intelligence is a theory of intelligence that differentiates it into specific (primarily sensory) 'modalities', rather than seeing intelligence as dominated by one general ability.[1] This model was proposed by Howard Gardner who stated eight criteria as an

This research was financially supported by:

1. Science Foundation for Returnees of Heilongjiang Province: A Study on the Key Technology of Improvement System of Spoken English Based on the Mobile Intelligence Terminal (Grant No.: LC2015026)

2. Philosophy and Social Sciences Research Program of Heilongjiang Province: A Study on Ecological Module of Business English Talents Developing in Heilongjiang Province (Grant No.: 15EDB01) intelligence: potential for brain isolation by brain damage; place in evolutionary history; presence of core operations; susceptibility to encoding (symbolic expression); a distinct developmental progression; the existence of savants; prodigies and other exceptional people; support from experimental psychology and psychometric findings.

According to Gardner, eight types of abilities that can meet the criteria: musical-rhythmic,visual-spatial, verballinguistic, logical-mathematical, bodily-kinesthetic, interpersonal, intrapersonal, and naturalistic. Although the distinction between intelligence has been set out in great detail, Gardner opposes the idea of labeling learners to a specific intelligence. Each individual possesses a unique blend of all the intelligence. Gardner firmly maintains that his theory of multiple intelligence should "empower learners", not restrict them to one modality of learning. An intelligence is "a biopsychological potential to process information that can be activated in a cultural setting to solve problems or create products that are of value in a culture."[2]

The Multiple Intelligence Theory has four important features. First, it emphasizes the integrality. The eight kinds of intelligence are equally important. Learners should pay equal attention to the eight kinds of intelligence. Second, it attaches importance to the otherness. Although human being's intelligence is relatively independent, the eight kinds of intelligence in each person have their own characteristic due to the influence of different environment and the restriction of the level of education. And the next feature is the practicalness. The intelligence means the ability of solving the problems in real life and discovering new knowledge. The last feature is the development. The key of influencing the level of multiple intelligence is on the development of ourselves.[3]

\section{PROBLEMS IN SPOKEN ENGLISH STUdIES GUIDED BY MULTIPLE INTELLIGENCE THEORY}

This paper studies how to improve English speaking studies under the guidance of the four aspects of multiple intelligence theory.

\section{A. Problems from the Perspective of Integrality}

Traditionally, in the process of second language learning, there is not a favourable environment to introduce students how to study the second language. Many students do not 
have a clear idea about themselves and even have a wrong concept in their mind that is "I can't communicate with others do whatever I want. I must totally have not the talent of speaking." [4] The influence of that is extremely bad because it strangles the students' possibility and future from the aspect of language. In fact, many times, the reason why the results do not reach our target is that the students do not fully use their strength but use their weakness when they study.

1) Excessive emphasis on verbal linguistic intelligence:The core of learning a second language is verbal linguistic intelligence. The expression of business English is also rich in varied forms. In various business scenarios, the way of learning is different. Sometimes, the verbal linguistic intelligence is not useful as other intelligence. And if we emphasize verbal linguistic intelligence excessively, that will impede other intelligences' development, even crack down the enthusiasm of study. [5]

On the other hand, excessively emphasizing verbal linguistic intelligence will lead us to ignore other intelligence and cause the resource squander. It is not the best way of learning.

2) Monotonous Way of Study: In China, the traditional learning theory is behavioristic psychology ${ }^{[6]}$. For behavioral pattern, behaviourists lay stress on explicitness and observability and they also think the study is not related with student's mental activities.

Based on this understanding, in traditional learning activities, the role of student is always in passive state. A most popular and general idea has directly reflected this situation that is students are learning in accordance with requirements. The basic concept of this learning theory is that all students can reach the same result in the same time. This concept totally obliterates the individual difference and ignores the diversity of learning style, knowledge structure and self-demand.

\section{B. Problems from the Perspective of Otherness}

In the related works of multiple intelligence theory, it explained that we should attach importance to the individual difference. And it points out the remarkable difference between each student makes people think that should students learn business spoken English in the same course or even the course same, should the learning way be different? In fact, due to the different environments of living, human beings' intelligence is totally different. Therefore, if ignoring these diversities and insisting on all students should learn as the same way, the result will be doomed as failure. Only little students can reach the good performance in business spoken English learning.

1) Imprecise understanding of multiple intelligence: Traditional intelligence theory, like the theory of intelligence and Piaget's cognitive development theory, all agree that intelligence is an integrate ability which core is language and mathematical logic. In the process of business oral English learning, many students think verbal intelligence is the only intelligent way of learning business oral English, and that is limiting their mind of learning. [6]

Multiple intelligence theory assumes that, in terms of its basic structure, intelligence is diverse, and it is not a kind of ability, but rather a set of skills. Besides, the various ability in the group is not in the form of integration, but in the form of relatively independent existence. This also means that in business English learning process, we can not only through verbal intelligence to learn, but also can through the musical intelligence, bodily kinesthetic intelligence, visual spatial intelligent and various intelligence to study business spoken English.

2) Lack of understanding of inter-individual disparity: Intelligence is a kind of biological potential. Gardner believes that intelligence is the original biological potential and it is the unique ability to human. In the study of psychology, more and more evidence has showed that people are born with a certain intelligence which is good at something than others. We can see some children are extremely sensitive with numbers, words or voice. ${ }^{[7]}$ In some certain areas, the stimulus of their respond is fast and they are enjoyable to that. It means that some individuals have strong potential in some ways. But in the process of learning, many students don't have this consciousness and a clear understanding of the difference between the individual.

\section{Problems from the Perspective of Practicalness}

Practicalness, on the other hand, can be called creativity, referring to the ability to solve practical problems in real life and discover new knowledge. But under the mode of traditional business oral English learning, the pattern of learning is passive and receptive. Familiar with the text content, like listening to the tape, watching video and teaching by teacher, it is to simply use of the knowledge from the text content, like testing the content of the text understanding and grasping to the grammar, vocabulary and pattern, then to use knowledge to more complex as according to the content to process situational dialogues. [8] If we reach it on closer scrutiny, it is not hard to find that in the whole learning process, students do not actively involved in. They just passively complete the arrangement of tasks to the end. The abilities of discovering new knowledge and solving the problem are not promoted.

1) Lack of motivation of study: Because of the influence of the single receptive learning mode, many students are lack of initiative in the process of business oral English learning. Now, the situation is "teachers don't teach, students do not learn; teachers don't teach, students can't solve the problems". This is a kind of morbid way of learning. The result of this learning method is that all of the students are lack of awareness and motivation that students are the center of learning. And they do not the innovation in the study, only imitate blindly.

Therefore, many students may feel that "I have spent so much time on oral English learning, but I can't get any results". All of this is because we lack the initiative consciousness. 
2) Low ability of solving practical problems: Intelligence's functions are to solve a problem or create social value. Gardner believes that "a person's intelligence is bound to bring a set of problem-solving skills and it can make the individual solve their real problems or difficulties they have faced. If necessary, it also has the ability to make the individual create a product which is useful. And then, intelligence is bound to produce or create the potential to solve the problem."'[9]

This means that only when people solve the difficulties actively or create something that the society is valuing, can we call that is to be real in the use of the intelligence. Nowadays, however, students cannot find the solutions when there are some problems in the business communication with foreigners.

\section{Problems from the Perspective of Development}

Educator has played a very important role in the development of multiple intelligence. Every student has great potential in the development of one or several aspects, as long as you provide them the appropriate education and training and the corresponding intelligent of students can be developed.

However, the education does not create a diverse environment which is beneficial to discover, demonstrate and promote all kinds of intelligence, nor provide wide variety of choices for students' learning which enables students to foster strengths and circumvent weaknesses, stimulate the potential of intelligence and develop each personality.

1) Lack of attention to vulnerable areas: Confucius said:" the no child left behind." In school, there is not poor student and it only have a diamond in the rough who is different in characteristics, the different types of learning and intelligence ability. Teacher's main responsibility should be to let the students, in the existing curriculum system, realize the diversity of their own intellectual development and help students achieve advantage transformation. Instead, due to lack of the attention to the other intelligence of students except verbal linguistic intelligence, many teachers have become a destroyer to learning.

2) Sole evaluation criteria of study: One of the main problems of previous evaluation is that the evaluation is divorced from reality. And it often knows the student's capability and ability through a large amount of abstraction, structured knowledge. However, the result is many of the students who get high marks in the school evaluation find it is difficult to adapt to the requirement of the society.

Multiple intelligence evaluation theory attaches great importance to evaluation of the situation and the evaluation of students in real life. It reflects the students' real ability. The theory of multiple intelligence emphasizes the evaluation should pay attention to justice and equality. To let student know that all participation is right, the person who has the courage to speak English is good.

\section{SUGGESTIONS FOR SPOKEN ENGLISH IMPROVEMENT GUIDED BY MULTIPLE INTELLIGENCE THEORY}

Today, concerning about learner's speaking ability, there are endless problems. Intelligence, which is too often considered to be merely a matter of analytical ability measured and valued in T.Q. points depends on more of the brain and the body than we generally realize. Physical movement, from earliest infancy and throughout our lives, plays an important role in the creation of nerve cell networks which are actually the essence of learning. ${ }^{[10]}$ The right way to find the best learning methods is to use the superiority intelligence based on the multiple intelligence theory. And next, the paper will give some suggestions from four aspects.

\section{A. Suggestions from the Perspective of Integrality}

Multiple intelligence theory agrees that every student has one or several kinds of superior intelligence on the basis of comprehensive development of intelligence, that is, all-round development and personality can be balanceable and harmonious development.

Each learner has at least eight kinds of intelligence and on the influence of the proper environment and education, it can meet the level, that is the level of full development. Secondly, the structure of each learner's intelligence is different. And the difference is the personality what we need to pay more attention.

1) Grasping the multiple intelligence development of yourself: There are several ways to know our own cognitive development. Such as questionnaire survey, consulting the teacher and asking friends etc. And questionnaire is the fast. But in order to avoid the errors which are brought by various reasons, it is necessary to investigate further. The types of students' intelligence would more directly vividly displayed in our daily life. Therefore, try to observe and record ourselves various performance, especially to record the achievements, it is particularly important because the achievements always reflect student's strength. And at the same time, it also needs to record the "bad behavior" because the students' intellectual strengths often reveal inadvertently. For instance, the student who loves fidgeting is usually stronger in bodily kinesthetic intelligence and the student who loves interrupting is stronger in verbal linguistic intelligence.

2) Designing all-round intelligence learning methods: Guiding by the theory of multiple intelligence, the learning contents are more targeted and the learning methods are full of diversity.

Using the unit of Negotiation in business English learning as an example, first, from the multiple perspectives, students have a design to their learning content using modern teaching methods such as multimedia, network and projection to introduce the images, animation and text into study, inspired by the questions to cultivate students' logical mathematical intelligence and verbal linguistic intelligence. Before the formal negotiation, some of the students can hold a small conference to promote products, their phones. The 
rich background music and wonderful explanation have stimulated the students' musical intelligence and interpersonal intelligence. The manuscripts and drafting of negotiating preparing before the class had cultivated the students' intrapersonal intelligence and naturalist intelligence.

\section{B. Suggestions from the Perspective of Otherness}

We can say, the difference offered by the creator to human and even the whole world is the most wonderful thing. It makes this world so beauty. Similarly, in the process of oral English learning, differences are inevitable. There are differences between the students' interests, habits, learning methods and acceptance of knowledge, these are unavoidable. In fact, many people have a wrong idea in their mind, thought the personality brought about by difference is not a "vocation". However, respect the difference, embrace it and enjoy it, you will find its importance in the business oral English learning.

1) Respecting the individual difference: Respecting differences is the foundation of the whole learning process because each student's intelligence has a unique expression and each kind of intelligence can take on many forms. Thus, it is so hard to find a standard which is suited for everyone to evaluate his or her talent and success.

Under normal conditions, the individual can develop and strengthen any kind of intelligence, as long as there are proper stimulation and effort. There are three factors to influence the intelligence development, that is nature, personal growth and the background of history of living. ${ }^{[11]}$ These three factors are mutual influence and interaction. Although people's innate plays a determinative effect to the type of intelligence, the level of intelligence development depends more on the individual historical and cultural education activity.

2) Making full use of your superior intelligence: Compared with other students, each student has his or her unique advantage of intelligence, but at the same time, only in the purposeful, planned and organized learning activities, can student's intelligence be fully developed. The strength of some students' verbal linguistic intelligence is not obvious and the performance is bad, if we only pay attention to the verbal linguistic intelligence, those students may think their performance are bad and feel embarrassed. The final result is the "wounded pride" may lead to students lose interest in business oral English learning. Therefore, we can use various business topics in spoken English learning to show our intelligence and enjoy it.

\section{Suggestions from the Perspective of Practicalness}

Business The final purpose of learning is to solve the problem. Multiple intelligence theory insists that intelligence is the ability to solve the problem or create products in a particular cultural background and society. Intelligence is always associated with a certain cultural background and the language doesn't exist if it has nothing to do with its specific cultural background.
1) Setting goals before learning: The Learning must be with certain purposes. Multiple intelligence theory advocates the comprehensive goal of teaching which is unlike single goal of teaching of behaviorism. "According to my point of view, the aim of school education should be to develop a variety of smart and to help students find the suitable career and hobbies" ${ }^{\text {[12] }}$. Students must have their own deep understanding of a particular theme and have the ability of independently thinking and problem solving. The ultimate goal of education is to increase human understanding. Only having established the premise, can we know what we should learn and why we should study those lessons.

2) Enhancing the scene mutually learning: The problem of traditional evaluation is the testing situation. The content does not relate with real life but the measured results are often linked to real life. The reason is that the evaluation was conducted in artificial unnatural situation. It is a way of paper and pencil test, valuing theory more than practice and ignoring the creation ability assessment. It can't reflect student's ability to solve problems and innovation ability in real life situations. For example, we can form a training room as a training platform for students. Through this platform, students can simulate those business activities, like the company's marketing, foreign trade correspondence, business negotiation, documents making, document translation, customs clearance and the other business, which can motivate students' enthusiasm of practice.

In addition, the practice base also helps students improve the ability of solving problems through the way of perception, experience, practice and participation. Through contextualized learning, it is beneficial to cultivate students' comprehensive ability of business communication and promote the balanced development of students' multiple intelligence.

\section{Suggestion from the Perspective of Development}

The level of student's intelligence largely depends on the developing by their teacher. Learning from Gardner's multiple intelligence theory, if the teacher can give full play to student's initiative or excitement, using the strength intelligence to drive the weak intelligence, it will promote student's comprehensive intellectual development. The theory of multiple intelligence will also take the student as the center, attaches great importance to the learning process, through the rich teaching activities form to cultivate the students' intelligence in many aspects.

1) Transferring your inferior intelligence to superior one: We can explain this point from a case. Teddy is a little boy, introverted but with a strong independence. He only loves piling up his building blocks. It is a boy that whose advantage intelligence is outstanding but other intelligence is poor. Through the guiding and patiently allowing Teddy does what he likes, after three months, Teddy slowly turned into an open boy and all kinds of his intelligence have a comprehensive development. [13] 
The function of education is not just about "foster strengths and circumvent weaknesses", is more about to development in an all-around way. If the student does not perform well in the field of verbal linguistic intelligence, like Teddy's teacher did, educators should also have enough patience and wisdom to design various activities contained all kinds of intelligence and transfer the inferior intelligence to superior one.

2) Setting up multiple evaluation system: In the traditional evaluation patterns, the teacher is the main body, controlling everything. Now, students and teachers are both becoming the main participants of evaluation. Under the guidance of teachers, students will be making selfevaluation, mutual evaluation and the evaluation of teacher's teaching method. Besides, in the introduction of the concept of multiple intelligence in the oral English class, the course content is more specific and it is an urgent to make the corresponding evaluation standard. When showing their intelligence, students are looking forward to get a comprehensive evaluation, to made more progress towards personal goals.

\section{CONCLUSION}

In this new era, the theory of second language acquisition is increasingly developing toward the direction of being learner-centered, which is proposed by the multiple intelligence theory. As a result, we can apply the theory and deepen its connotation of the original learning method, cultivating the students' multiple intelligence like the prompt method which emphasizes a harmonious learning environment of student accompanied by pictures and music. It is not only developing the language cognitive ability of students but also improving student's musical intelligence.

The theory of multiple intelligence has brought a lot of enlightenment to the education and teaching practice in China, which is conductive to changing the single structure of learning mode of English and language testing. This witnesses a great shift from the teacher-centered language teaching to the student-centered way of tuition, which is not only teaching knowledge and skills but also training the student's multiple intelligence. We believe in the guidance of the theory of multiple intelligence, spoken English learning mode can be of more individuation and diversification, thus to educate more English talents for the society.

\section{REFERENCES}

[1] Armstrong, T. Multiple Intelligences in the Classroom. Alexandria, VA: ASCD, 2004

[2] Cooper, C. Intelligence and Abilities. Routledge Press, 2009.

[3] Ellis, D. Learning to Learn English: A Course in Learning Training. Cambridge: Cambridge University Press, 2008.

[4] Gardner, H. Frames of Mind: The Theory of Multiple Intelligence. New York: Basic Books Inc., 2013.

[5] Gardner, H. Multiple Intelligences:The Theory in Practice. New York: Basic Books Inc., 2013.

[6] Gardner, H. Intelligence Reframed, Multiple Intelligences for the 21st Century. New York: Basic Books, 2014.
[7] Hannaford, C. Smart Moves: Why Learning is Not All in Your Head. Arlington, VA: Great Ocean Publishers, 2015.

[8] Lazear, D. Seven Ways of Teaching: the Aristry of Teaching with Multiple Intelligences. Arlington Heights, IL: Skylight Publishing, 2007.

[9] Reid, J. Affect in Language Learning. Cambridge: Cambridge University Press, 2009.

[10] Zhang Jianhua, Liu Zhongying. The issue of knowledge management system model and the countermeasures and analysis[J]. Intelligence Academics.2004, 23(1):73-77. (in Chinese)

[11] Larsen-Freeman, D. and Long, M. An Introduction to Second Language Acquisition Research. Harlow, UK: Longman, 2000.

[12] Rogers, C. Humanistic Education Sourcebook. Englewood Cliffs, NJ: Prentice Hall, 1975.

[13] Xue Jinxiang. A Study on the construction of curriculum of Business English Major from the Perspective of Ecology[J]. Heilongjiang Higher Education Research, 2013(2): 163-165. (in Chinese) 